\title{
Compound heterozygosity for hemoglobin $S$ and hemoglobin $E$ in a family of Proto-Australoid origin: a case report
}

\author{
Noymi Basumatary ${ }^{1}$, Dipankar Baruah², Paresh Kumar Sarma ${ }^{3}$ and Jatin Sarmah ${ }^{4^{*}}$ (1)
}

\begin{abstract}
Background: Hemoglobin $\mathrm{S}$ and $\mathrm{E}$ are commonly occurring hemoglobin variants among distinctly separate tribal populations of Central and Northeast India, respectively. Combined heterozygosity for hemoglobin S and E or hemoglobin SE disease is a benign clinical condition with rare incidence. Reports of approximately 46 hemoglobin SE cases are available worldwide. We conducted a screening program to study the prevalence of hemoglobin variants among the tribal population working in the tea estates of Northeast India. A total of 551 subjects were screened, and complete blood count was performed. Based on their hematological profiles, hemoglobin typing was done for 218 subjects.
\end{abstract}

Case presentation: We describe a case of an adolescent male of Munda tribe diagnosed as double heterozygous for hemoglobin $\mathrm{S}$ and $\mathrm{E}$. On screening of the nuclear family of the subject, the mother was found to have hemoglobin $\mathrm{E}$ disease and father as hemoglobin $\mathrm{S}$ trait. Both siblings of the subject were diagnosed as hemoglobin $\mathrm{E}$ trait.

Conclusion: This is the first case of compound heterozygous for hemoglobin $\mathrm{S}$ and $\mathrm{E}$ to be reported from the tea tribes of Assam, India.

Keywords: Proto-Australoid, Hemoglobinopathy, Hemolytic anemia, Sickle cell disease, Tea tribe

\section{Background}

Hemoglobinopathies are monogenic disorders characterized by abnormal hemoglobin structure [1]. Among the hemoglobin variants, the most commonly occurring and clinically significant variants are hemoglobin $\mathrm{S}(\mathrm{Hb} \mathrm{S})$, hemoglobin $\mathrm{C}(\mathrm{Hb} \mathrm{C})$, hemoglobin $\mathrm{E}(\mathrm{Hb} \mathrm{E})$, and thalassemia [2]. In context to its occurrence, $\mathrm{Hb} \mathrm{E}$ is the second most common abnormal variant of hemoglobin in the world and most common variant in Southeast Asia [3]. Central-West Africa, East Asia, and India experience higher occurrence of sickle cell disease in comparison

\footnotetext{
*Correspondence: jatinsarmahindia@gmail.com

${ }^{4}$ Department of Biotechnology and Co-ordinator, DBT (Govt. of India) sponsored Bioinformatics Infrastructure Facility, Bodoland University, Kokrajhar, Assam, India

Full list of author information is available at the end of the article
}

with other parts of the world. Hemoglobinopathies are a cause of both economic and psychosocial burden [4]. Sickle cell disease shows an autosomal recessive inheritance resulting from $\mathrm{A}>\mathrm{T}$ mutation in the sixth residue of the $\beta$-globin chain. Hb E results from a Glu $\rightarrow$ Lys mutation in the 26th amino acid.

Among the different types of hemoglobinopathies, prevalence of $\mathrm{Hb} \mathrm{S}$ and $\mathrm{Hb} \mathrm{E}$ in India is $4.3 \%$ and $10.9 \%$ respectively [5]. The burden of hemoglobinopathies in India is so high that it has become a major public health issue in some parts of the country [3]. In India, prevalence of $\mathrm{Hb} \mathrm{S}$ among the tribals of central, southern, and western part has been reported [6]. In the eastern and northeastern part, $\mathrm{Hb} \mathrm{E}$ is prevalent [7]. Sickle cell disease, particularly, has turned into a major health concern in states such as Chhattisgarh, Maharashtra, Gujarat, 
Jharkhand, Madhya Pradesh, and Odisha, demanding serious attention.

A large workforce is employed in the tea estates of Assam, which constitutively forms the tea-tribe community. These laborers were brought to Assam by British rulers from the present states of Chhattisgarh, West Bengal, Odisha, and Jharkhand during the last part of the nineteenth century. Ethnically, they belong to the Proto-Australoid race and are of Austro-Asiatic language group. High prevalence of sickle cell anemia among the Adivasi (ab-origin) population of mainland India has been reported [6]. We conducted a study to investigate the prevalence of sickle cell disorder among the tea estate laborers of Udalguri District of Assam, India.

\section{Case presentation}

The present study was approved by the Institutional Ethics Committee of Bodoland University, Kokrajhar, Assam, India vide Ref. No.:-IEC/BU/ICMR/2019-2 dated $10 / 05 / 2019$. Consent was obtained from the participants prior to blood collection. Complete blood count (CBC) was conducted for 551 apparently healthy laborers of both sexes. Based on the hematological profiles, namely, hemoglobin $(\mathrm{Hb}) \%$, mean corpuscular volume (MCV), mean corpuscular hemoglobin $(\mathrm{MCH})$, and mean corpuscular hemoglobin concentration $(\mathrm{MCHC})$ of the subjects by Sysmex Hematology Analyzer (XP-100), Hb electrophoresis was performed in 218 cases in Sebia Minicap Automated Capillary Electrophoresis system. In an adolescent male of 17 years of age from a Munda family, one peak was detected in the $\mathrm{Hb} \mathrm{S}$ zone and another in the $\mathrm{Hb} \mathrm{E}$ zone (Fig. 1A). On the basis of Hb electrophoresis chromatogram, the case was confirmed to be double heterozygous for $\mathrm{Hb} \mathrm{S}$ and $\mathrm{Hb} \mathrm{E}(\mathrm{Hb} \mathrm{SE})$ trait. Based on the finding, we performed screening for all members of the nuclear family.

Hematological profiles of the members of the family are presented in Table 1 . The case subject showed low $\mathrm{Hb}(7.8 \mathrm{~g} / \mathrm{dl}), \mathrm{MCHC}(29.3 \%)$, and RBC count $\left(2.34\right.$ million $\left./ \mathrm{mm}^{3}\right)$. Other parameters such as $\mathrm{MCV}$

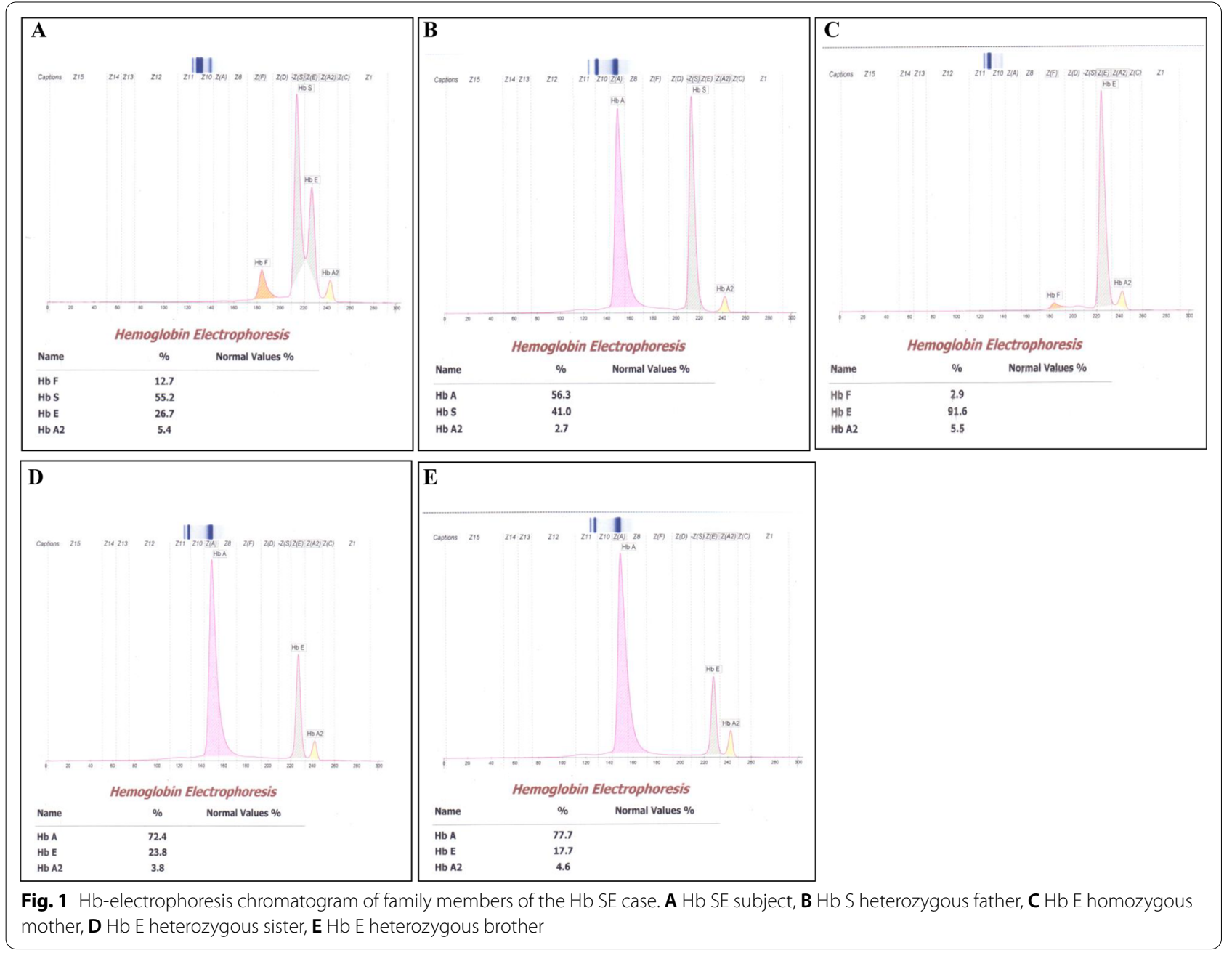


Table 1 Hematological profile of the nuclear family of $\mathrm{Hb}$ SE case

\begin{tabular}{|c|c|c|c|c|c|}
\hline \multirow[t]{2}{*}{ Parameters } & \multicolumn{5}{|l|}{ Relation } \\
\hline & Subject & Father & Mother & Sister & Brother \\
\hline $\mathrm{Hb}(\mathrm{g} / \mathrm{dl})$ & 7.8 & 13.9 & 10.5 & 7.1 & 11.6 \\
\hline RBC (million $/ \mathrm{mm}^{3}$ ) & 2.34 & 4.92 & 3.64 & 3.1 & 4.34 \\
\hline MCV (fl) & 114 & 94 & 98 & 84 & 93 \\
\hline $\mathrm{MCH}(\mathrm{pg})$ & 33.3 & 28.3 & 28.8 & 22.7 & 26.6 \\
\hline $\mathrm{MCHC}(\mathrm{g} / \mathrm{dl})$ & 29.3 & 30.1 & 29.4 & 27 & 28.6 \\
\hline RDW (\%) & 18.5 & 12.1 & 17.6 & 22.2 & 17.4 \\
\hline $\mathrm{Hb} F(\%)$ & 12.7 & 0.0 & 2.9 & 0.0 & 0.0 \\
\hline $\mathrm{Hb} \mathrm{A}(\%)$ & 0.0 & 56.3 & 0.0 & 72.4 & 77.7 \\
\hline $\mathrm{Hb} \mathrm{A}_{2}(\%)$ & 5.4 & 2.7 & 5.5 & 3.8 & 4.6 \\
\hline $\mathrm{Hb} \mathrm{S}(\%)$ & 55.2 & 41.0 & 0.0 & 0.0 & 0.0 \\
\hline Hb E (\%) & 26.7 & 0.0 & 91.6 & 23.8 & 17.7 \\
\hline
\end{tabular}

$\mathrm{Hb}$ : hemoglobin; RBC: red blood cell; $\mathrm{MCV}$ : mean corpuscular volume; $\mathrm{MCH}$ : mean corpuscular hemoglobin; MCHC: mean corpuscular hemoglobin concentration; RDW: red cell distribution width

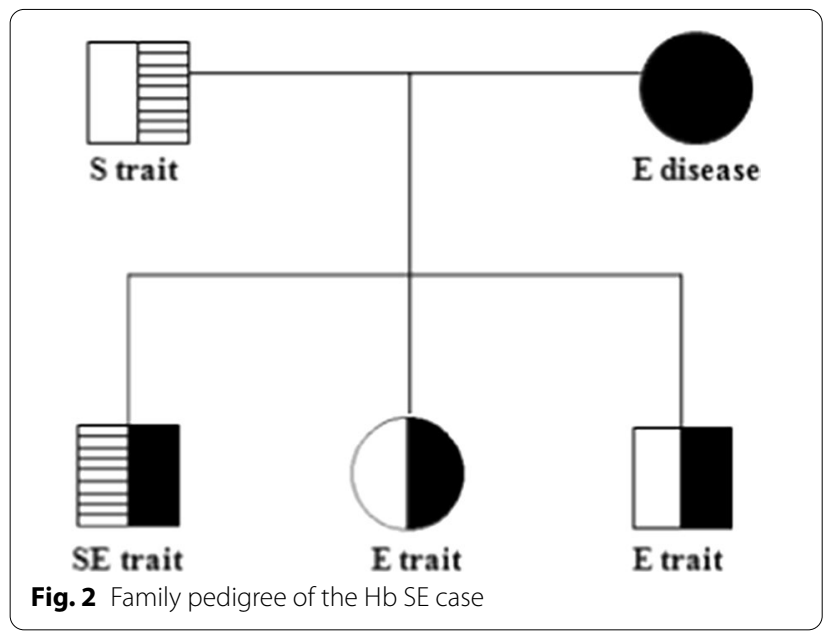

(114 fl), $\mathrm{MCH}$ (33.3 pg), and red cell distribution width (RDW) (18.5\%) were higher than the normal values. $\mathrm{Hb}$ electrophoresis showed $12.7 \% \mathrm{Hb} \mathrm{F}, 5.4 \% \mathrm{Hb} \mathrm{A}_{2}$, $55.2 \% \mathrm{Hb} \mathrm{S}$, and $26.7 \% \mathrm{Hb}$ E. The case subject was an academically average senior secondary student with no previous record of medication. His body weight and height were $63.9 \mathrm{~kg}$ and $5^{\prime} 7^{\prime \prime}$, respectively. Family screening revealed his father as $\mathrm{Hb} \mathrm{S}$ heterozygous (Fig. 1B) and mother as Hb E homozygous (Fig. 1C). Both siblings of the subject were also diagnosed as $\mathrm{Hb}$ E trait (Fig. 1D, E). Family tree of the Hb SE case is shown in Fig. 2. Collection of marriage history data from the District Marriage Registry Office did not show any record of intermarriage of the case subject's family with Mongoloid race.

\section{Discussion}

The tribals of Central India (including Munda tribe) are racially different from the tribals of northeastern part of India. Tribals of Chhattisgarh, West Bengal, Odisha, and Jharkhand are Austro-Asiatic speakers of ProtoAustraloid race, whereas the tribals of Northeast India are Tibeto-Burman speaking group of Mongoloid origin. Reports on existence of $\mathrm{Hb} \mathrm{S}$ and $\mathrm{Hb} \mathrm{E}$ separately among the tea tribe of Assam are well known [8]. However, compound heterozygosity for $\mathrm{Hb} \mathrm{S}$ and $\mathrm{Hb} \mathrm{E}$ was not reported earlier from any community from the multiethnic and multiracial population of Northeast India. $\mathrm{Hb}$ $\mathrm{SE}$ is a hemoglobin variant having an effect on $\beta$-globin gene [9]. Patients detected with $\mathrm{Hb}$ SE disease showed a substitution of glutamic acid by lysine at 26th position of $\beta$-globin chain [10]. Such double heterozygous condition was reported from a 15-year-old Teli male (Other Backward Caste) from Central India who complained of frequent upper respiratory tract infections, weakness, and fatigue [11]. In our report, compound heterozygosity for $\mathrm{Hb} \mathrm{S}$ and $\mathrm{Hb} \mathrm{E}$ trait has been presented. Even though the case is anemic, he did not show any other symptoms including transfusion dependency. Unlike other hemoglobinopathies, $\mathrm{Hb}$ SE symptoms appear in the late childhood stage or after 20 years [12]. Hematological profile of the subject showed decreased $\mathrm{Hb}, \mathrm{MCHC}$, and RBC count and increased $\mathrm{MCV}, \mathrm{MCH}$, and RDW values. $\mathrm{Hb}$ electrophoresis showed $12.7 \%$ of $\mathrm{Hb} \mathrm{F}, 5.4 \%$ of $\mathrm{Hb} \mathrm{A}_{2}$, $55.2 \%$ of $\mathrm{Hb} \mathrm{S}$, and $26.7 \%$ of $\mathrm{Hb}$ E. Earlier workers have commented that the hematological parameters and $\mathrm{Hb}$ levels do not help in identifying the clinical severity of the condition [13]. Earlier workers also commented that the presence of greater amount of $\mathrm{Hb} F$ and lesser amount of $\mathrm{Hb} \mathrm{S}$ decreases the appearance of clinical symptoms of the patient [14].

Interaction of $\mathrm{Hb} \mathrm{S}$ heterozygous father with $\mathrm{Hb} \mathrm{E}$ homozygous mother has given rise to composite heterozygosity for $\mathrm{Hb} \mathrm{S}$ and $\mathrm{Hb} \mathrm{E}$. On investigation of family history for the last five generations, both parents of the subject had no record of intermarriage with the tribals of Mongoloid origin. The case subject's siblings diagnosed as $\mathrm{Hb}$ E heterozygous also showed low MCHC and RBC counts, with other parameters as normal or slightly higher than the normal values. $\mathrm{Hb} \mathrm{SE}$ is a clinically benign and rare condition with variable clinical manifestations or even asymptomatically [10]. Some may show mild symptoms, and in some cases the condition may be more severe such as hemolytic episodes with frequent blood transfusions, whereas in some cases the person may be asymptomatic other than being anemic, 
as in the present study. Sudden death of an Hb SE person of 12 years of age after exercise was also reported with ventricular septal cardiac defect at the time of birth, mild asthma, and fractures of radius and ulna 17 months prior to death [15]. These variations in clinical manifestations of the disorder have made its diagnosis difficult. As a result, they are diagnosed occasionally only during examination for other medical complaint [16].

\section{Conclusion}

$\mathrm{Hb} \mathrm{S}$ is seen among the tribal population of Central India, and $\mathrm{Hb} \mathrm{E}$ is common among the tribals of Northeastern Region of India. Prevalence of $\mathrm{Hb} \mathrm{S}$ among the tea tribe population can be attributed to their migration from the central India. This is the first report of occurrence of double heterozygous for $\mathrm{Hb} \mathrm{S}$ and $\mathrm{E}$ among the Proto-Australoid tribal population of this region.

\author{
Abbreviations \\ $\mathrm{Hb}$ S: Hemoglobin S; Hb E: Hemoglobin E; Hb SE: Hemoglobin SE; Hb C: \\ Hemoglobin C; CBC: Complete blood count; Hb: Hemoglobin; MCV: Mean \\ corpuscular volume; MCH: Mean corpuscular hemoglobin; MCHC: Mean \\ corpuscular hemoglobin concentration; RDW: Red cell distribution width; RBC: \\ Red blood cell; $\mathrm{Hb}$ F: Hemoglobin fetal; $\mathrm{Hb} \mathrm{A}_{2}$ : Hemoglobin adult.
}

\section{Acknowledgements}

We gratefully acknowledge the Lady Tata Memorial Trust, Mumbai, India for providing Junior Scholarship to Miss Noymi Basumatary.

\section{Authors' contributions \\ NB performed the field work, collection of data from offices, and laboratory works, and prepared the manuscript. DB was responsible for all hematological tests and interpretation of results. PKS was responsible for physical examina- tion and analysis of medical history. JS conceived the idea and logistics, and guided and proofread the manuscript. All authors contributed equally to the work and approved the final manuscript. All authors read and approved the final manuscript.}

\section{Funding}

The work is sponsored by the Lady Tata Memorial Trust, Mumbai, India by offering Junior Scholarship to Miss Noymi Basumatary with effect from 12 September 2018. The scholarship also includes contingency grant for field work, purchase of chemicals, reagents, etc.

\section{Availability of data and materials}

Data will be made available to the publisher as and when sought.

\section{Declarations}

\section{Ethics approval and consent to participate}

The present work was approved by the Institutional Ethics Committee of Bodoland University, Kokrajhar, Assam, India vide Ref. No.: IEC/BU/ICMR/2019-2 of dated 10/05/2019. Consent was obtained from the participants to take part in the study and for blood collection.

\section{Consent for publication}

Written informed consent was obtained from the patient for publication of this case report and any accompanying images. A copy of the written consent is available for review by the Editors-in-Chief of this journal.

\section{Competing interests}

The authors declares that they have no competing interests.

\section{Author details}

'Department of Biotechnology, Bodoland University, Kokrajhar, Assam, India. ${ }^{2}$ Department of Pathology, Fakhruddin Ali Ahmed Medical College and Hospital, Barpeta, Assam, India. ${ }^{3}$ Department of Medicine, Fakhruddin Ali Ahmed Medical College and Hospital, Barpeta, Assam, India. ${ }^{4}$ Department of Biotechnology and Co-ordinator, DBT (Govt. of India) sponsored Bioinformatics Infrastructure Facility, Bodoland University, Kokrajhar, Assam, India.

Received: 15 May 2020 Accepted: 18 June 2021

Published online: 02 August 2021

\section{References}

1. Weatherall DJ. Hemoglobinopathies worldwide: present and future. Curr Mol Med. 2008;8:592-9.

2. Williams TN, Weatherall DJ. World distribution, population genetics, and health burden of the hemoglobinopathies. Cold Spring Harb Perspect Med. 2012. https://doi.org/10.1101/cshperspect.a011692.

3. Jazeera S, Feroze M. Compound heterozygosity for Hemoglobin E \& B Thalassemia: a family study from Kerala. Int J Med Sci Diag Res. 2019:3:34-8.

4. Shivashankara AR, Jailkhani R, Kini A. Hemoglobinopathies in Dharwad, North Karnataka: a hospital-based study. J Clin Diag Res. 2008;593-9.

5. Balgir RS. Public health challenges of hemoglobinopathies in tribal land in India: a necessity of introducing genetic services in the Health Care Systems approach. Br Biomed Bull. 2014;2:489-503.

6. Colah R, Mukherjee M, Ghosh K. Sickle cell disease in India. Curr Opin Hematol. 2014;21:215-23.

7. Mohanty D, Pathare AV. Sickle cell anemia - the Indian scenario. Indian J Hematol Blood Transfus. 1998;16:1-2.

8. Teli AB, Deori R, Saikia SP. Hemoglobinopathies and $\beta$-thalassaemia among the tribals working in the tea estates of Assam. India J Clin Diagn Res. 2016. https://doi.org/10.7860/JCDR/2016/22010.9002.

9. Bachir D, Galacteros F. Hemoglobin E disease. Orphanet Encyclopedia; 2004;1-4.

10. Gurkan E. Vaso-occlusive manifestations in a patient with sickle cellhemoglobin E (Hb SE) disease. Am J Hematol. 2006;81:149-56.

11. Dani AA, Shrikhande AV. Double heterozygous for hemoglobin $S$ and hemoglobin E-a case report from central India. Indian J Hematol Blood Transfus. 2007;23:119-21.

12. Knox-Macaulay HHM, Ahmed MM, Gravell D, Al-Kindi S, Ganesh A. Sickle cell-hemoglobin E (Hb SE) compound heterozygosity: a clinical and hematological study. Int J Lab Hem. 2007;29:292-301.

13. Mishra P, Pati HP, Chatterjee T, Dixit A, Choudhary DR, Srinivas MU, Mahapatra M, Choudhry VP. Hb SE disease: a clinico-hematological profile. Ann Hematol. 2005;84:667.

14. Dessap AM, Contou D, Dandine-Roulland C, Hemery F, Habibi A, CharlesNelson A, Galacteros F, Brun-Buisson C, Maitre B, Katsahian S. Environmental influences on daily emergency admissions in sickle-cell disease patients. Medicine. 2014;93:280.

15. Arbefeville EF, Tebbi CK, Chrostowski L, Adams VI. Sudden death after exercise in an adolescent with Hemoglobin SE. Am J Forensic Med Pathol. 2011;32:341-3.

16. Tauseef U, Anjum M, Ibrahim M, Baqai HS, Tauseef A, Tauseef M, Asghar MS, Zafar M, Rasheed U, Shaikh N. Occurrence of unusual hemoglobinopathies in Balochistan: $\mathrm{Hb}$ SD and $\mathrm{Hb}$ SE-presentation with osteomyelitis. Rev Paul Pediatr. 2021;39:2019365.

\section{Publisher's Note}

Springer Nature remains neutral with regard to jurisdictional claims in published maps and institutional affiliations. 